\title{
Activation of the Nrf2/HO-1 signaling pathway contributes to the protective effects of coptisine against oxidative stress-induced DNA damage and apoptosis in HaCaT keratinocytes
}

\author{
Yung Hyun Choi ${ }^{1,2}$ \\ ${ }^{1}$ Department of Biochemistry, Dong-eui University College of Korean Medicine, Busan, Republic of Korea \\ ${ }^{2}$ Anti-Aging Research Center, Dong-eui University, Busan, Republic of Korea
}

\begin{abstract}
In this study, the protective effect of coptisine on the oxidative damage-mediated apoptosis was evaluated in cultured human $\mathrm{HaCaT}$ keratinocytes. The results demonstrate that preincubation of cells with coptisine prior to $\mathrm{H}_{2} \mathrm{O}_{2}$ stimulation resulted in significant inhibition of cytotoxicity and DNA damage associated with the inhibition of reactive oxygen species (ROS) accumulation. Coptisine also restored $\mathrm{H}_{2} \mathrm{O}_{2}$-induced mitochondrial dysfunction and decrease of ATP production, and prevented apoptosis by inhibiting $\mathrm{Bax} / \mathrm{Bcl}-2$ ratio, caspase-3 activity, and poly(ADP-ribose) polymerase degradation. Interestingly, the expressions of nuclear factor-erythroid-2-related factor 2 (Nrf2) and its active form, phosphorylated Nrf2, were strikingly promoted by coptisine in the presence of $\mathrm{H}_{2} \mathrm{O}_{2}$, which was associated with a marked increase in the expression of heme oxygenase-1 (HO-1). However, coptisine-induced HO-1 expression was completely abrogated by Nrf2-specific small interfering RNA (Nrf2-siRNA), which suggests that the increased expression of HO- 1 by coptisine is Nrf2-dependent. In addition, Nrf2-siRNA transfection significantly eliminated the protective effect of coptisine on $\mathrm{H}_{2} \mathrm{O}_{2}$-induced cytotoxicity, and this effect was similar to that by zinc protoporphyrin IX ( $\mathrm{ZnPP})$, an HO-1 specific inhibitor. Furthermore, the protective effects of coptisine against $\mathrm{H}_{2} \mathrm{O}_{2}$-induced cytotoxicity were abolished by $\mathrm{ZnPP}$, indicating that coptisine protects keratinocytes against oxidative stress-induced injury through activation of the Nrf2/HO-1 signaling pathway.
\end{abstract}

Key words: Coptisine - Keratinocytes - ROS - DNA damage - Apoptosis - Nrf2/HO-1

\section{Introduction}

While adequate levels of reactive oxygen species (ROS) act as signaling molecules to maintain normal cellular function, excessive ROS production due to balance disturbances between pro-oxidant and antioxidant systems causes oxidative damage to most tissues (Valko et al. 2016; Treberg et al. 2019). In particular, ROS was found to be crucially involved in the induction of DNA damage and cell death by ultraviolet B (UVB) irradiation in skin cells (Kulms and Schwarz 2002; D'Errico et al. 2007). Among the intracellular organelles, mitochondria are the major source of ROS

Correspondence to: Yung Hyun Choi, Department of Biochemistry, Dong-eui University College of Korean Medicine, 52-57, Yangjeong-ro, Busanjin, Busan 47227, Republic of Korea E-mail: choiyh@deu.ac.kr production in keratinocytes exposed to UVB, and are the most vulnerable targets of ROS (Piao et al. 2012; Rezvani et al. 2007). Moreover, the accumulation of ROS beyond the antioxidant function of cells could reduce mitochondrial membrane potential (MMP), an index of the electron transport chain performance, resulting in compromised ATP production (Rigoulet et al. 2011; Sosa et al. 2013). Subsequently, apoptogenic proteins, including cytochrome $c$, are released from the mitochondrial intermembrane space into the cytoplasm, and play a central role in an induction signal for apoptosis (Finkel and Holbrook 2000; Rigoulet et al. 2011). Therefore, supplementation of antioxidants has been proposed as a strategy to prevent ROS generation through the activation of signaling pathways that inhibit free radical accumulation.

Coptisine is a naturally occurring isoquinoline alkaloid compound with a similar parent structure to berberine de- 
rived from Coptidis Rhizoma, the roots of Coptis chinensis Franch, which has been widely used in traditional medicine for the treatment of a number of diseases (Xu et al. 2017; Meng et al. 2018). Many previous studies have shown that this compound has beneficial multi-pharmacological effects, including antioxidant activity (Cho et al. 2004; Yokozawa et al. 2004; Jang et al. 2009; Jung et al. 2009). For example, Coptidis Rhizoma alkaloids, including coptisine, have been reported to protect DNA damage by nitric oxide (NO)-agonist drug in renal tubular epithelial cells by blocking peroxynitrite $\left(\mathrm{ONOO}^{-}\right)$formation (Yokozawa et al. 2004), which suggests that coptisine may be useful for the development of pharmacological agents for the treatment of disorders associated with oxidative stress. In addition, coptisine has been shown to improve cardiac systolic and diastolic dysfunction, and to ameliorate mitochondrial respiratory dysfunction by high doses of isoproterenol, a synthetic catecholamine and $\beta$-adrenergic agonist, due to its strong antioxidant activity (Gong et al. 2012). Moreover, recent studies have shown that coptisine acts as a powerful ROS scavenger through activating the nuclear factorerythroid-2-related factor 2 (Nrf2) signaling pathway, and can effectively exacerbate oxidative stress ( $\mathrm{Hu}$ et al. 2017; Luo et al. 2018). These antioxidant defense effects of Nrf2 signal transduction by coptisine seem to play an important role in regulating cell proliferation and apoptosis. Zinc protoporphyrin IX $(\mathrm{ZnPP})$, on the other hand, is a type of metalloporphyrins found in red blood cells when heme production is suppressed (Cheng et al. 2012; Kuribayashi et al. 2015). ZnPP competitively suppresses the activity of heme oxygenase-1 (HO-1), one of the major genes regulated by $\mathrm{Nrf2}$, due to its similarity to heme in the porphyrin loop structure, and reduce bilirubin production rates. Due to this characteristic, $\mathrm{ZnPP}$ is widely used as a blocker of $\mathrm{HO}-1$ activity (Fang et al. 2009; Hjortsø and Andersen 2014). However, no studies have been reported on the protective effect of coptisine against oxidative stress in skin cells. The aim of this study was to explore the usefulness of coptisine as part of a program to find defensive substances against oxidative stress (hydrogen peroxide, $\mathrm{H}_{2} \mathrm{O}_{2}$ ) in cultured HaCaT human skin keratinocytes.

\section{Materials and Methods}

\section{Cell culture and coptisine treatment}

HaCaT keratinocyte cell line was obtained from the American Type Culture Collection (Manassas, MD, USA), and maintained in RPMI 1640 medium (WelGENE Inc., Daegu, Republic of Korea) containing 10\% (v/v) heat-inactivated fetal bovine serum (WelGENE Inc.), streptomycin $(100 \mu \mathrm{g} /$ $\mathrm{ml})$, and penicillin (100 Units $/ \mathrm{ml})$ at $37^{\circ} \mathrm{C}$ in a humidified atmosphere containing 5\% $\mathrm{CO}_{2}$ and $95 \%$ air. Coptisine $\left(\mathrm{C}_{19} \mathrm{H}_{14} \mathrm{NO}_{4}{ }^{+}\right.$, purity $\left.\geq 98 \%\right)$, which was purchased from Sigma-Aldrich Chemical Co. (St. Louis, MO, USA), was dissolved in dimethyl sulfoxide (DMSO, Sigma-Aldrich Chemical Co.), and diluted with cell culture medium to adjust the final treatment concentrations, prior to use in the experiments. For the cell viability study, HaCaT cells were treated with different concentrations of coptisine for $24 \mathrm{~h}$, or pretreated with coptisine for $1 \mathrm{~h}$, before $\mathrm{H}_{2} \mathrm{O}_{2}(0.5 \mathrm{mM}$, Sigma-Aldrich Chemical Co.) treatment for $24 \mathrm{~h}$. The cells were also treated with $10 \mu \mathrm{M}$ ZnPP (Sigma-Aldrich Chemical Co.), a well established HO-1 inhibitor, for $1 \mathrm{~h}$ in the presence or absence of $\mathrm{H}_{2} \mathrm{O}_{2}$.

\section{Cell viability assay}

After completion of treatment, the medium was removed, and $0.5 \mathrm{mg} / \mathrm{ml}$ of 3-(4,5-dimethylthiazol-2-yl)-2,5-diphenyltetrazolium bromide (MTT, Sigma-Aldrich Chemical Co.) was added to each well, and incubated at $37^{\circ} \mathrm{C}$ for $3 \mathrm{~h}$. The supernatant was then replaced with an equal volume of DMSO to dissolve the blue formazan crystals for $10 \mathrm{~min}$. Optical density was measured at a wavelength of $540 \mathrm{~nm}$ with a microplate reader (Dynatech Laboratories, Chantilly, VA, USA). All experiments were performed in triplicate, and the results were expressed as the percentage of MTT reduction, assuming that the absorbance of control was $100 \%$.

\section{Small interfering RNA (siRNA) transfection}

siRNA-mediated silencing of the Nrf2 gene was performed using siRNA duplexes purchased from Santa Cruz Biotechnology, Inc. (Santa Cruz, CA, USA). In brief, the HaCaT cells were seeded $\left(1 \times 10^{4}\right.$ cells $\left./ \mathrm{ml}\right)$ in 6 -well culture plates, and Nrf2-siRNAs and control siNRAs were transfected into the cells using the Lipofectamine 2000 reagent (Life Technologies, Carlsbad, CA, USA), according to the manufacturer's instructions. The transfected cells were pretreated with or without coptisine and/or $\mathrm{ZnPP}$ for $1 \mathrm{~h}$, before adding $\mathrm{H}_{2} \mathrm{O}_{2}$ for a further $24 \mathrm{~h}$.

\section{Western blot analysis}

After being subjected to the necessary experimental treatments, the cells were harvested, washed with phosphate buffered saline (PBS), and lysed with lysis buffer for $30 \mathrm{~min}$ to extract whole-cell proteins, as described in the previous study (Kim et al. 2018). Protein concentrations were quantified using a Bio-Rad protein analysis kit (Bio-Rad Lab., Hercules, CA, USA), and the equal amounts (40 $\mu \mathrm{g})$ of protein samples were subjected to sodium dodecyl sulfate-polyacrylamide (SDS)-gel electrophoresis, and then 
transferred onto polyvinylidene fluoride membranes (Millipore, Bedford, MA, USA). Membranes were blocked with $5 \%$ bovine serum albumin (Sigma-Aldrich Chemical Co.) for $1 \mathrm{~h}$ in a mixture of Tris-Buffered Saline and Tween-20 (TBST), and probed with primary antibodies overnight at $4^{\circ} \mathrm{C}$. The primary antibodies against Nrf2, Keap1, poly(ADPribose) polymerase (PARP), Bax, Bcl-2 and caspase- 3 were purchased from Santa Cruz Biotechnology, Inc. (Dallas, TX, USA). Antibody for phosphor (p)-Nrf2 was obtained Abcam, Inc. (Cambridge, UK). The primary antibodies against histone variant H2A.X $(\gamma \mathrm{H} 2 \mathrm{~A} . \mathrm{X})$ and $\mathrm{p}-\gamma \mathrm{H} 2 \mathrm{~A} . \mathrm{X}$ were purchased from Cell signaling Technology (Danvers, MA, USA). Anti-HO-1 and anti-actin antibodies were obtained from Calbiochem-Novabiochem Co. (San Diego, CA, USA) and Bioworld Technology, Inc. (St Louis Park, MN, USA), respectively. The membranes were then incubated with the appropriate secondary antibodies conjugated with horseradish peroxidase (Santa Cruz Biotechnology, Inc.) for $2 \mathrm{~h}$ at room temperature, and rinsed three times with TBST. The protein bands were visualized by incubating the membranes in an enhanced chemiluminescence (ECL) reagent (Amersham Biosciences, Westborough, MA, USA), according to the manufacturer's instructions. The immunoreactive bands were detected and exposed to X-ray film. Images of Western blotting were also analyzed using Image (Vilber Lourmat, Torcy, France).

\section{Measurement of ROS}

Intracellular ROS levels were assessed by staining cells using the oxidation-sensitive dye $2^{\prime}, 7^{\prime}$-dichlorofluorescein diacetate (DCF-DA). In brief, cells were washed twice with cold PBS, suspended in PBS, and stained with $10 \mu \mathrm{M}$ DCFDA (Sigma-Aldrich Chemical Co.) for $20 \mathrm{~min}$ at $37^{\circ} \mathrm{C}$ in the dark. Relative fluorescence intensities of cell suspensions were measured using a flow cytometer (Becton Dickinson, San Jose, CA, USA). To assess intracellular ROS production by image analysis, cells were seeded on a coverslip loaded 6-well plate for $24 \mathrm{~h}$, treated with coptisine and/or ZnPP for $1 \mathrm{~h}$, and then with $\mathrm{H}_{2} \mathrm{O}_{2}$ for $1 \mathrm{~h}$. After washing with PBS, cells were stained with $10 \mu \mathrm{M} \mathrm{DCF}-\mathrm{DA}$ for $20 \mathrm{~min}$ at $37^{\circ} \mathrm{C}$, washed, and mounted on microscope slides using mounting medium (Sigma-Aldrich Chemical Co.). The images were obtained using a fluorescence microscope (Carl Zeiss, Oberkochen, Germany).

\section{Comet assay for DNA damage}

DNA damage in individual cells was assessed using an alkaline comet assay, as previously described (Park et al. 2018). Cells were seeded on 6-well plates at a density of $3 \times 10^{5}$ cells/well for $24 \mathrm{~h}$, and treated with or without coptisine and/or $\mathrm{ZnPP}$ for $1 \mathrm{~h}$, before adding $\mathrm{H}_{2} \mathrm{O}_{2}$ for a further $24 \mathrm{~h}$. The cells were detached from culture surfaces, mixed with $0.75 \%$ low-melting agarose (LMA), and transferred to a microscope slide precoated with a layer of 0.75\% normal-melting agarose. After solidification, slides were covered with LMA, and immersed in lysis solution (2.5 M NaCl, $100 \mathrm{mM} \mathrm{Na-ethylenediaminetetraacetic} \mathrm{acid}$ (EDTA), $10 \mathrm{mM}$ Tris, $1 \%$ Triton X-100, and 10\% DMSO $(\mathrm{pH} \mathrm{10)})$ for $1 \mathrm{~h}$ at $4^{\circ} \mathrm{C}$ to remove proteins. The slides were then placed in a horizontal electrophoresis tank containing electrophoresis buffer (300 mM NaOH, 10 mM Na-EDTA, $\mathrm{pH}$ 10) for $20 \mathrm{~min}$, to allow DNA unwinding under alkaline/neutral conditions. Thereafter, electrophoresis was conducted in the same buffer for $20 \mathrm{~min}$ at $4^{\circ} \mathrm{C}$, to draw negatively-charged DNA towards the anode. Slides were then rinsed gently three times with neutralization buffer (0.4 M Tris- $\mathrm{HCl}, \mathrm{pH} 7.5$ ) for $10 \mathrm{~min}$ at $25^{\circ} \mathrm{C}$, stained with ethidium bromide (EtBr, $10 \mu \mathrm{g} / \mathrm{ml}$, Sigma-Aldrich Chemical Co.), and observed under a fluorescence microscope. All of the steps above were conducted under yellow light to prevent DNA damage.

\section{Determination of 8-hydroxy-2'-deoxyguanosine (8-OHdG)}

The BIOXYTECH ${ }^{\oplus} 8$-OHdG-EIA ${ }^{\text {TM }}$ kit (OXIS Health Products Inc., Portland, OR, USA) was used to quantify oxidative DNA damage. Briefly, cells were pretreated with or without coptisine and/or $\mathrm{ZnPP}$ for $1 \mathrm{~h}$, prior to treatment with $\mathrm{H}_{2} \mathrm{O}_{2}$ in the presence or absence of coptisine. After $24 \mathrm{~h}$ culture, cellular DNA was isolated using a DNA extraction kit (iNtRON Biotechnology Inc., Sungnam, Republic of Korea), and quantified according to the manufacturer's protocol. The amount of 8-OHdG, a deoxyriboside form of 8-oxoguanine, in DNA was found using a standard curve by measuring the absorbance at $450 \mathrm{~nm}$, using a microplate reader according to the manufacturer's instructions.

\section{Measurement of MMPs $(\Delta \Psi m)$}

To assess MMP losses, cells were collected after respective treatments, and incubated in media containing $10 \mu \mathrm{M}$ of JC-1 (5,5'6,6'-tetrachloro-1,1'3,3'-tetraethyl-imidacarbocyanine iodide; Sigma-Aldrich Chemical Co.), a mitochondriaspecific fluorescent dye, for $20 \mathrm{~min}$ at $37^{\circ} \mathrm{C}$ in the dark. After washing twice with PBS to remove unbound dye, green (JC-1 monomers) to red (JC-1 aggregates) fluorescence ratios were determined by flow cytometer, according to the manufacturer's instructions.

\section{Determination of ATP levels}

Intracellular ATP levels were determined using a fireflyluciferase-based ATP Bioluminescence Assay Kit (Roche Applied Science, Indianapolis, IN, USA). Briefly, cells cultured 
under various conditions were lysed with the provided lysis buffer, and collected supernatants were mixed with an equal amount of luciferase agent, which catalyzed the reaction between ATP and luciferin. Emitted light was immediately measured using a microplate luminometer, and ATP levels were calculated using a standard curve.

\section{Colorimetric assay of caspase-3 activity}

Caspase- 3 activity was assessed using a colorimetric assay kit (R\&D Systems, Minneapolis, MN, USA). In brief, the collected cells were lysed, and equal amounts of proteins were incubated with the supplied reaction buffer, which contained the caspase- 3 substrates dithiothreitol and tetrapeptides (Asp-Glu-Val-Asp(DEAD)-p-nitroaniline (pNA)), for $2 \mathrm{~h}$ at $37^{\circ} \mathrm{C}$ in the dark. Changes in absorbance at $405 \mathrm{~nm}$ were determined using a microplate reader, according to the manufacturer's instructions. Results are presented as multiples of untreated control cell values.

\section{Apoptosis assay using a fluorescence microscope}

Apoptosis induction was evaluated by observing nuclear morphological changes. After treating cells with $\mathrm{H}_{2} \mathrm{O}_{2}$ in the presence or absence of coptisine and/or $\mathrm{ZnPP}$, the cells were harvested, washed with PBS, and then fixed with $4 \%$ paraformaldehyde (Sigma-Aldrich Chemical Co.) in PBS for $30 \mathrm{~min}$ at room temperature. Cells were then permeabilized with $0.1 \%(\mathrm{w} / \mathrm{v})$ Triton X-100 for $5 \mathrm{~min}$, stained with $1.0 \mathrm{mg} /$ $\mathrm{ml}$ of 4,6-diamidino-2-phenylindole (DAPI, Sigma-Aldrich Chemical Co.) solution for $10 \mathrm{~min}$ at room temperature in the dark, and washed twice with PBS. Nuclear morphologic changes were examined using a fluorescence microscope.

\section{Apoptosis analysis using a flow cytometer}

Apoptosis extents were determined by flow cytometry using Annexin V/propidium iodide (PI) double staining. In brief, cells were collected, rinsed with PBS, re-suspended in binding buffer, and stained with fluorescein isothiocyanate (FITC)-conjugated annexin V and PI (BD Pharmingen, San Diego, CA, USA) at room temperature for $20 \mathrm{~min}$ in the dark, according to the manufacturer's instructions. Cell fluorescence intensities were detected using a flow cytometer, and data were analyzed using Cell Quest Pro software. Annexin ${ }^{-} / \mathrm{PI}^{+}$cells were considered normal, whereas annexin $\mathrm{V}$-FITC ${ }^{+} / \mathrm{PI}^{-}$and annexin ${ }^{+} / \mathrm{PI}^{+}$were considered indicators of early and late apoptotic cells, respectively.

\section{Internucleosomal DNA fragmentation assay}

The collected cells were dissolved in lysis buffer $(10 \mathrm{mM}$ Tris- $\mathrm{HCl}$ (pH 7.4), 150 mM NaCl, 5 mM EDTA, 0.5\% Triton
$\mathrm{X}-100$, and $0.1 \mathrm{mg} / \mathrm{ml}$ proteinase $\mathrm{K}$ ) for $30 \mathrm{~min}$ at room temperature. DNA from the supernatant was extracted by chloroform/phenol/isoamyl alcohol (24/25/1, v/v/v), and was precipitated by ethanol. The extracted DNA was then transferred to $1.5 \%$ agarose gel containing $0.1 \mu \mathrm{g} / \mathrm{ml}$ $\mathrm{EtBr}$, and electrophoresis was carried out at $70 \mathrm{~V}$. The gel was visualized using a Chemidox (Bio-Rad Lab., Hercules, CA, USA).

\section{Statistical analysis}

All experiments were performed at least three times. Data were analyzed using GraphPad Prism software (version 5.03; GraphPad Software, Inc., La Jolla, CA, USA), and expressed as the mean \pm standard deviation (SD). Differences between groups were assessed using analysis of variance followed by ANOVA-Tukey's post hoc test, and $p<0.05$ was considered to indicate a statistically significant difference.

\section{Results}

\section{Coptisine inhibited $\mathrm{H}_{2} \mathrm{O}_{2}$-induced cytotoxicity in $\mathrm{HaCaT}$ keratinocytes}

$\mathrm{HaCaT}$ cells were treated with various concentrations of coptisine and $\mathrm{H}_{2} \mathrm{O}_{2}$ for $24 \mathrm{~h}$, and the MTT assay was performed to establish the experimental conditions. Figure $1 \mathrm{~A}$ shows that $\mathrm{HaCaT}$ cells treated with concentrations of $75 \mu \mathrm{g} / \mathrm{ml}$ or more revealed a significant decrease in cell viability, but no significant change until $50 \mu \mathrm{g} / \mathrm{ml}$ treatment, compared to the control group. Therefore, the concentration range of coptisine was selected to be less than $50 \mu \mathrm{g} / \mathrm{ml}$ to verify antioxidant efficacy. $\mathrm{H}_{2} \mathrm{O}_{2}$ concentration for oxidative stress induction was selected to be $0.5 \mathrm{mM}$, which was about $60 \%$ survival rate, compared with control cells (data not shown). To evaluate the protective effect of coptisine on $\mathrm{H}_{2} \mathrm{O}_{2}$-induced cytotoxicity, $\mathrm{HaCaT}$ cells were pretreated with 10,25 , and $50 \mu \mathrm{g} / \mathrm{ml}$ coptisine for $1 \mathrm{~h}$ before treatment with $0.5 \mathrm{mM} \mathrm{H}_{2} \mathrm{O}_{2}$, and cultured for $24 \mathrm{~h}$. Figure $1 \mathrm{~B}$ shows that pretreatment with 25 and $50 \mu \mathrm{g} / \mathrm{ml}$ coptisine significantly restored cell viability, as compared to $\mathrm{H}_{2} \mathrm{O}_{2}$ alone, in a concentrationdependent manner.

\section{Coptisine activated the Nrf2/HO-1 signaling pathway in HaCaT keratinocytes}

To investigate whether the cytoprotective activity of coptisine on $\mathrm{H}_{2} \mathrm{O}_{2}$ was correlated with the activation of $\mathrm{Nrf} 2$ signaling, the effect of coptisine on the expression of Nrf2 and its regulatory genes was determined. The immunoblotting results showed that the expression of $\mathrm{Nrf} 2$ protein 
A

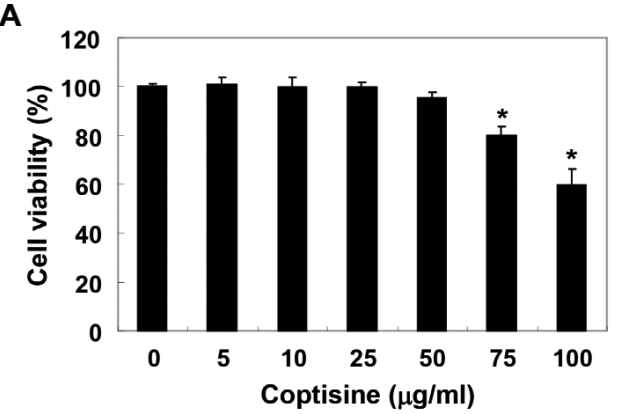

B

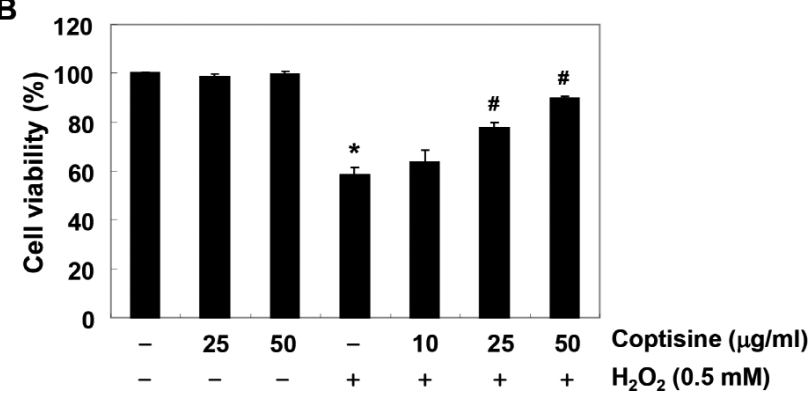

Figure 1. Effects of coptisine on the $\mathrm{H}_{2} \mathrm{O}_{2}$-induced cytotoxicity in $\mathrm{HaCaT}$ cells. Cells were treated with the indicated concentrations of coptisine for $24 \mathrm{~h} \mathrm{(A)}$, or pre-treated with or without coptisine for $1 \mathrm{~h}$, and then stimulated with $0.5 \mathrm{mM} \mathrm{H}_{2} \mathrm{O}_{2}$ for $24 \mathrm{~h}(\mathbf{B})$. Cell viability was assessed by MTT reduction assay $\left({ }^{*} p<0.05\right.$ compared with the control group, ${ }^{\#} p<0.05$ compared with the $\mathrm{H}_{2} \mathrm{O}_{2}$-treated group).

was slightly increased in the $\mathrm{H}_{2} \mathrm{O}_{2}$ alone group, and more than that in the $50 \mu \mathrm{g} / \mathrm{ml}$ coptisine treated group (Figures $2 \mathrm{~A}$ and $\mathrm{B})$. However, the expression of $\mathrm{Nrf2}$ protein was markedly increased in $\mathrm{H}_{2} \mathrm{O}_{2}$-treated cells in the presence of coptisine compared to $\mathrm{H}_{2} \mathrm{O}_{2}$ and coptisine alone, and the expression of the phosphorylated form of $\mathrm{Nrf2}$ ( $\mathrm{p}-\mathrm{Nrf} 2$, at serine 40), which meant that Nrf2 was activated, was also markedly increased in the co-treatment group. In addition, the increase in coptisine-induced activation of Nrf2 was accompanied by an induction of HO-1 expression, but the expression of Kelch-like ECH associated protein 1 (Keap1) was decreased in a coptisine treatment-dependent manner. Therefore, a loss-of-function experiment using siRNA was performed to investigate whether the increase in HO-1 expression by coptisine is an Nrf2-dependent phenomenon. When transiently transfected with Nrf2 specific siRNA (Nrf2-siRNA), as shown in Figures 2C and $\mathrm{D}$, the increased expression of Nrf2, $\mathrm{p}-\mathrm{Nrf} 2$, and $\mathrm{HO}-1$ in cells co-treated with coptisine and $\mathrm{H}_{2} \mathrm{O}_{2}$ was effectively abolished. Consequently, the expression of Keap1 in the cells treated with Nrf2-siRNA was maintained at the control level, which means that the augmentation of HO-1 expression by coptisine is Nrf2-dependent.
The protective effect of coptisine on $\mathrm{H}_{2} \mathrm{O}_{2}$-induced $\mathrm{HaCaT}$ cell cytotoxicity was Nrf2/HO-1 signaling dependent

Next, the relationship between the activation of Nrf2 / HO-1 signaling by coptisine and the protective effect against oxidative stress were determined. As shown in Figure 2E, Nrf2 expression interference significantly eliminated the effect of improving the cell viability of coptisine against $\mathrm{H}_{2} \mathrm{O}_{2}$ treatment, demonstrating that $\mathrm{Nrf} 2 / \mathrm{HO}-1$ signaling plays a critical role in the coptisine protective effect of $\mathrm{H}_{2} \mathrm{O}_{2}$ induced oxidative stress in $\mathrm{HaCaT}$ cells. It was also found that the protective effect of coptisine was reversed by blocking the activation of HO- 1 by ZnPP, a HO-1 selective inhibitor (Figure 2F). These results indicate that Nrf2-mediated HO-1 expression by coptisine in $\mathrm{HaCaT}$ cells is an important mediator in inhibiting $\mathrm{H}_{2} \mathrm{O}_{2}$-induced cytotoxicity.

\section{Coptisine attenuated $\mathrm{H}_{2} \mathrm{O}_{2}$-induced ROS generation in HaCaT keratinocytes}

The effect of coptisine on the production of ROS by $\mathrm{H}_{2} \mathrm{O}_{2}$ was examined to further investigate whether the protective effect of coptisine on $\mathrm{H}_{2} \mathrm{O}_{2}$-induced cytotoxicity was due to the blockade of oxidative stress. For this purpose, the production of ROS was examined using a fluorescent labeled probe, DCF-DA, and the fluorescence intensity was markedly increased within $1 \mathrm{~h}$ in the cells exposed to $\mathrm{H}_{2} \mathrm{O}_{2}$ compared to the control (Figures $3 \mathrm{~A}$ and $\mathrm{B}$ ). However, the accumulation of ROS in $\mathrm{HaCaT}$ cells pretreated with coptisine was significantly reduced compared to in those with $\mathrm{H}_{2} \mathrm{O}_{2}$ alone treatment. In addition, the fluorescence microscope observation again confirmed that coptisine had a powerful ROS scavenging effect (Figure 3C). However, the suppression of HO- 1 activity by ZnPP offset the inhibitory effect of coptisine on ROS production, indicating that the cytoprotective effects of coptisine on oxidative stress may be mediated by ROS generation blockade through HO-1 activation.

\section{Coptisine reduced $\mathrm{H}_{2} \mathrm{O}_{2}$-induced DNA damage in $\mathrm{HaCaT}$ keratinocytes}

To determine whether coptisine prevents DNA damage, the effect of coptisine on the $\mathrm{H}_{2} \mathrm{O}_{2}$-induced phosphorylation of $\gamma \mathrm{H} 2 \mathrm{AX}$ protein ( $\mathrm{p}-\gamma \mathrm{H} 2 \mathrm{AX}$, at serine 139$)$, one of the DNA strand break markers, was assessed. The immunoblotting results of Figures $4 \mathrm{~A}$ and $\mathrm{B}$ show that the marked increase in $\mathrm{p}-\gamma \mathrm{H} 2 \mathrm{AX}$ in $\mathrm{H}_{2} \mathrm{O}_{2}$-stimulated cells was reduced by pretreatment with coptisine compared to untreated control cells, without altering the expression of total $\gamma \mathrm{H} 2 \mathrm{AX}$ protein. Additionally, in the comet assay, another method for detecting DNA strand breaks, there was no smeared pattern of nuclear DNA in untreated control and coptisine alone treated cells. However, in $\mathrm{H}_{2} \mathrm{O}_{2}$-stimulated cells, the length of the comet 
tail clearly increased, which means DNA damage occurred; and in coptisine pretreated cells, tail length was obviously shorter than in $\mathrm{H}_{2} \mathrm{O}_{2}$-treated cells (Figure $4 \mathrm{C}$ ). Furthermore, $\mathrm{H}_{2} \mathrm{O}_{2}$ treatment significantly increased the production of
8-OHdG adduct, a specific marker of DNA oxidative damage, compared to the control group, but pretreatment of coptisine significantly reduced the production of $8-\mathrm{OHdG}$ by $\mathrm{H}_{2} \mathrm{O}_{2}$ (Figure $4 \mathrm{D}$ ). On the other hand, $\mathrm{ZnPP}$ excluded
A

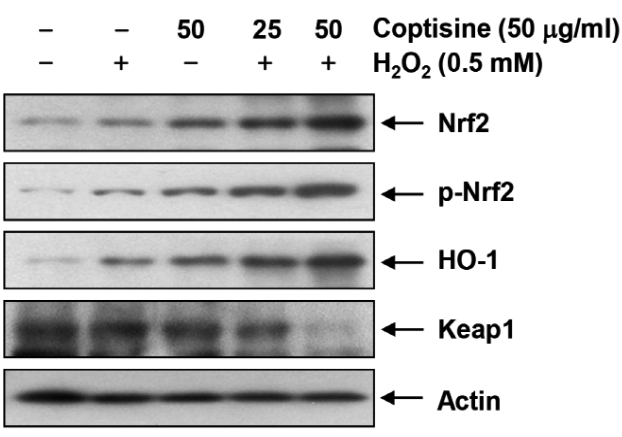

C

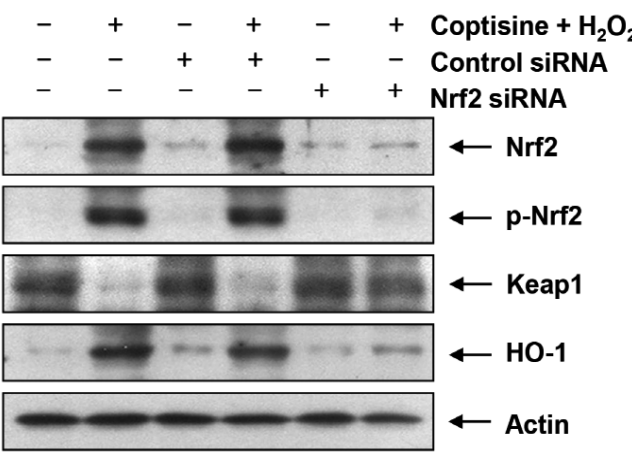

E

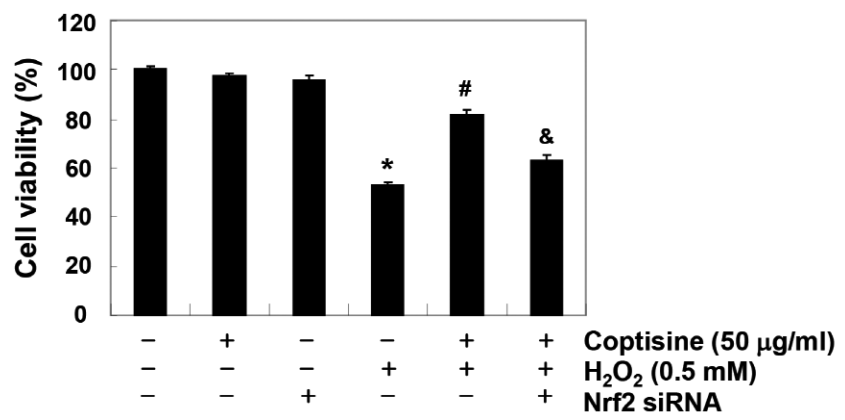

B

D

$\mathbf{F}$
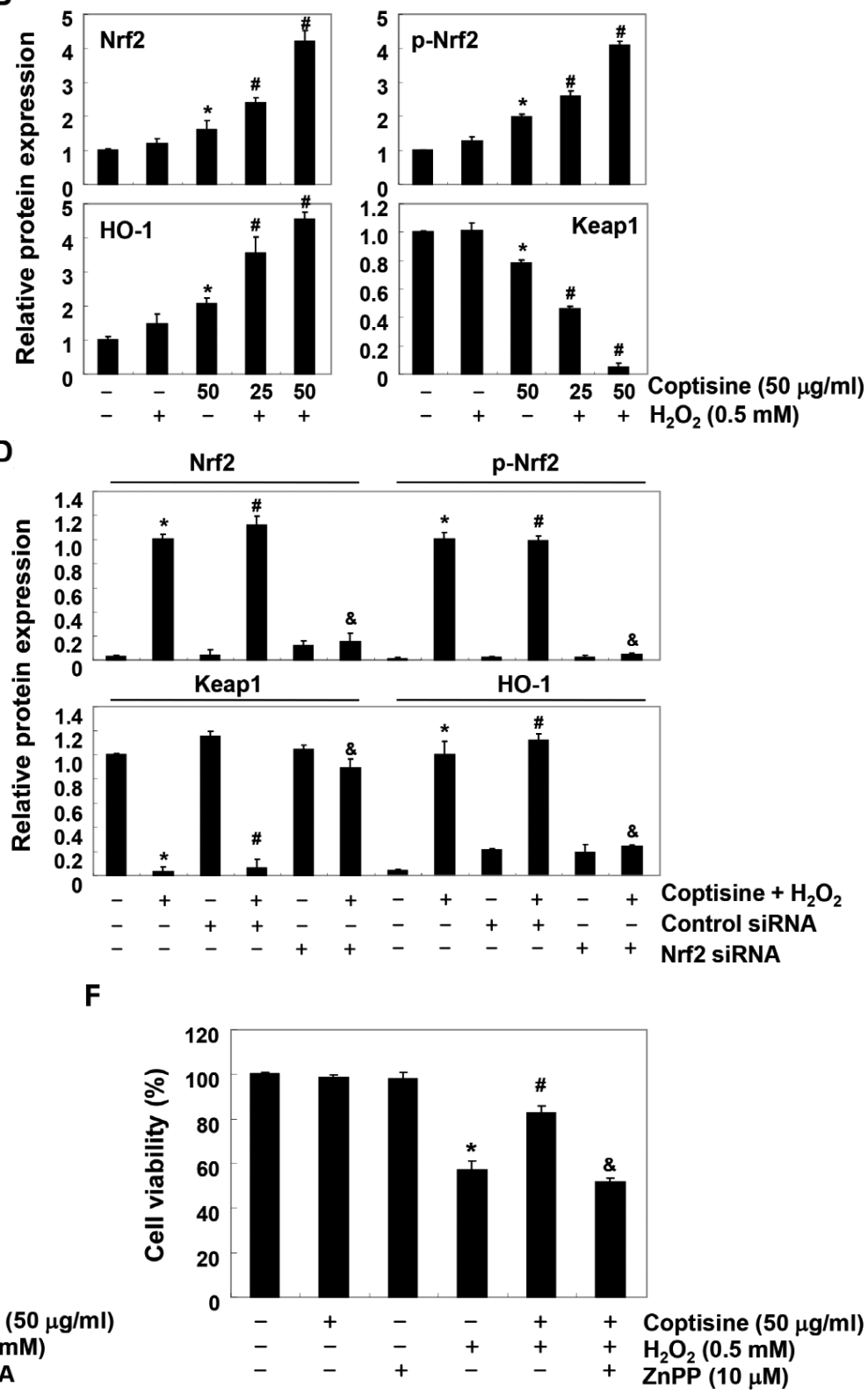

Figure 2. Involvement of $\mathrm{Nrf2} / \mathrm{HO}-1$ signaling in the protective effect of coptisine on $\mathrm{H}_{2} \mathrm{O}_{2}$-induced $\mathrm{HaCaT}$ cell cytotoxicity. A., B. Cells were pretreated with or without the indicated concentrations of coptisine for $1 \mathrm{~h}$, and then stimulated with $0.5 \mathrm{mM} \mathrm{H}_{2} \mathrm{O}_{2}$ for $24 \mathrm{~h}$. C., E. Cells transfected with or without Nrf2-siRNA or control siRNA were pretreated with $50 \mu \mathrm{g} / \mathrm{ml} \mathrm{coptisine} \mathrm{for} 1 \mathrm{~h}$, and then stimulated with or without $0.5 \mathrm{mM} \mathrm{H}_{2} \mathrm{O}_{2}$ for $24 \mathrm{~h}$. F. Cells were pretreated with $50 \mu \mathrm{g} / \mathrm{ml}$ coptisine and/or $10 \mu \mathrm{M} \mathrm{ZnPP}$ for $1 \mathrm{~h}$, and then stimulated with or without $0.5 \mathrm{mM} \mathrm{H}_{2} \mathrm{O}_{2}$ for $24 \mathrm{~h}$. A., C. Cell lysates were subjected to gel electrophoresis, and then Western blot analysis was performed using the indicated antibodies. Actin was used as an internal control. B., D. Bands were quantified using ImageJ, normalized to actin and ratios were determined. E., F. The cell viability was estimated using an MTT assay $\left({ }^{*} p<0.05\right.$ compared with the control group, ${ }^{\#} p<0.05$ compared with the $\mathrm{H}_{2} \mathrm{O}_{2}$-treated group, ${ }^{\&} p<0.05$ compared with the coptisine and $\mathrm{H}_{2} \mathrm{O}_{2}$-treated group). 


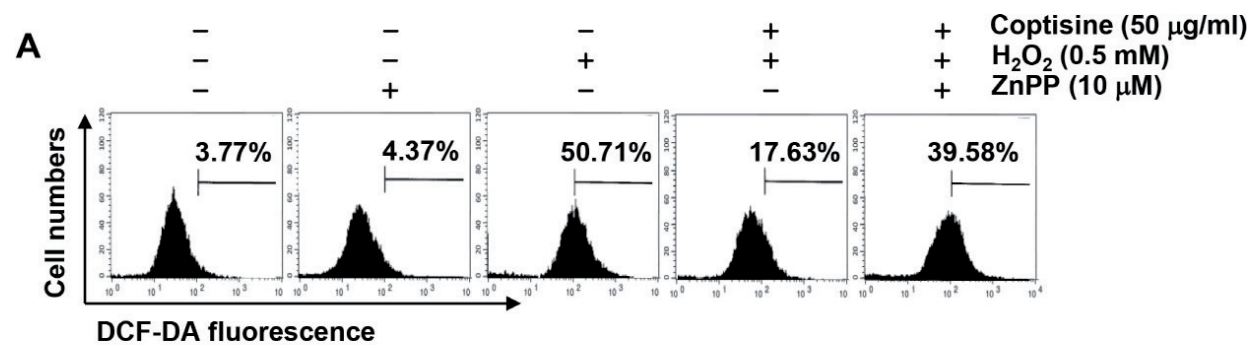

\section{B}

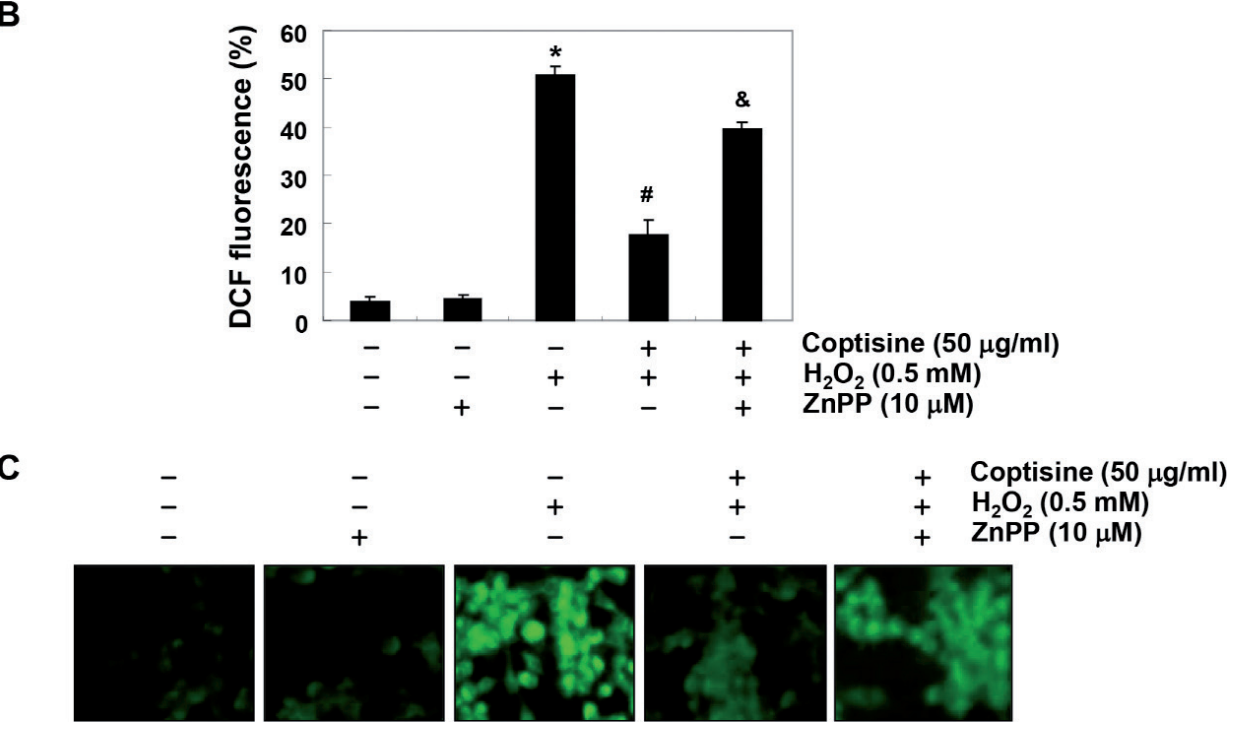

Figure 3. Protection of $\mathrm{H}_{2} \mathrm{O}_{2}$ induced ROS generation by coptisine in HaCaT cells. Cells were pretreated with $50 \mu \mathrm{g} / \mathrm{ml}$ coptisine and/or $10 \mu \mathrm{M} \mathrm{ZnPP}$ for $1 \mathrm{~h}$, and then stimulated with or without $0.5 \mathrm{mM} \mathrm{H}_{2} \mathrm{O}_{2}$ for 1 h. A., B. After staining with DCF-DA fluorescent dye, DCF fluorescence was monitored by a flow cytometer $\left({ }^{*} p<0.05\right.$ compared with the control group, ${ }^{\#} p<0.05$ compared with the $\mathrm{H}_{2} \mathrm{O}_{2}$-treated group, ${ }^{\&} p<0.05$ compared with the coptisine and $\mathrm{H}_{2} \mathrm{O}_{2}$-treated group). C. Images were obtained by a fluorescence microscope (original magnification, 200 $)$.

all of coptisine's protective effect against DNA damage by $\mathrm{H}_{2} \mathrm{O}_{2}$, suggesting that the cytoprotective effect of coptisine on oxidative stress-induced DNA damage in HaCaT cells is mediated through HO-1 induction.

Coptisine diminished $\mathrm{H}_{2} \mathrm{O}_{2}$-induced mitochondrial dysfunction in $\mathrm{HaCaT}$ keratinocytes

In order to examine the protective effect of coptisine on mitochondrial dysfunction by $\mathrm{H}_{2} \mathrm{O}_{2}, \mathrm{MMP}$ and intracellular ATP levels were evaluated. According to the results of JC- 1 staining shown in Figures $5 \mathrm{~A}$ and B, changes in the ratio of polarized and depolarized cell populations were observed in $\mathrm{HaCaT}$ cells treated with $\mathrm{H}_{2} \mathrm{O}_{2}$, and the increase in depolarized mitochondrial membrane was significantly higher than in the control group. In agreement with this result, the concentration of ATP in cells exposed to $\mathrm{H}_{2} \mathrm{O}_{2}$ was significantly reduced, compared with in cells cultured in normal medium (Figure 5C). However, coptisine was able to prevent these changes, and the protective effects of coptisine were significantly abrogated in the presence of $\mathrm{ZnPP}$, demonstrating that the activation of $\mathrm{HO}-1$ was involved in this protective activity.
Coptisine suppressed $\mathrm{H}_{2} \mathrm{O}_{2}$-induced apoptosis in $\mathrm{HaCaT}$ keratinocytes

DAPI staining, flow cytometry, and agarose gel electrophoresis analyses were further performed, to investigate whether the cytoprotective effect of coptisine against $\mathrm{H}_{2} \mathrm{O}_{2}$ on $\mathrm{HaCaT}$ cells was related to apoptosis suppression. The fluorescent images in Figure 6A reveal that the control cells had intact nuclei, while the $\mathrm{H}_{2} \mathrm{O}_{2}$-treated cells showed significant chromatin condensation, which is observed in the apoptosis-induced cells. However, the morphological changes were markedly attenuated in the cells pretreated with coptisine before the treatment with $\mathrm{H}_{2} \mathrm{O}_{2}$. The results of Annexin V/PI double staining also showed that the pretreatment of coptisine significantly decreased the frequency of apoptotic cells in $\mathrm{H}_{2} \mathrm{O}_{2}$-stimulated cells (Figures $6 \mathrm{~B}$ and $\mathrm{C}$ ). In addition, $\mathrm{H}_{2} \mathrm{O}_{2}$-induced DNA fragmentation, another evidence of the apoptosis induction, was markedly attenuated in cells treated with coptisine prior to $\mathrm{H}_{2} \mathrm{O}_{2}$ stimulation (Figure 6D). Worth noting, $\mathrm{ZnPP}$ also excluded the beneficial effects of coptisine on $\mathrm{H}_{2} \mathrm{O}_{2}$-induced apoptosis, indicating that the protective role of coptisine was at least dependent on HO-1. 
Coptisine restored $\mathrm{H}_{2} \mathrm{O}_{2}$-induced alteration of the apoptosis regulatory genes in $\mathrm{HaCaT}$ keratinocytes

To investigate the mechanisms of apoptosis-protective effect of coptisine and the role of $\mathrm{HO}-1$, the effect of coptisine and $\mathrm{ZnPP}$ on $\mathrm{H}_{2} \mathrm{O}_{2}$-induced changes of apoptosis regulatory genes expression was finally examined. The immunoblotting results of Figures 7A and B show that anti-apoptotic Bcl-2 protein was significantly down-regulated in $\mathrm{H}_{2} \mathrm{O}_{2}$-treated HaCaT cells, while the pro-apoptotic Bax protein was upregulated. In addition, the expression of pro-caspase-3 was markedly reduced. However, expression of active caspase- 3 was not detected under the same conditions. Thus, the in vitro activity of caspase- 3 was measured and its activity was found to be increased about 4-fold in $\mathrm{H}_{2} \mathrm{O}_{2}$-treated cells compared to the control (Figure 7C), which was associated with the degradation of PARP, a representative substrate protein degraded by activated caspase- 3 (Figures $7 \mathrm{~A}$ and $\mathrm{B}$ ). However, these changes by $\mathrm{H}_{2} \mathrm{O}_{2}$ treatment were relatively conservative in the coptisine-pretreated cells, and the protective potentials of coptisine disappeared under the condition in which the activation of $\mathrm{HO}-1$ was suppressed.

\section{Discussion}

Overload of intracellular ROS due to the imbalance of ROS production and defense of antioxidant systems can oxidize

A

$\mathbf{B}$
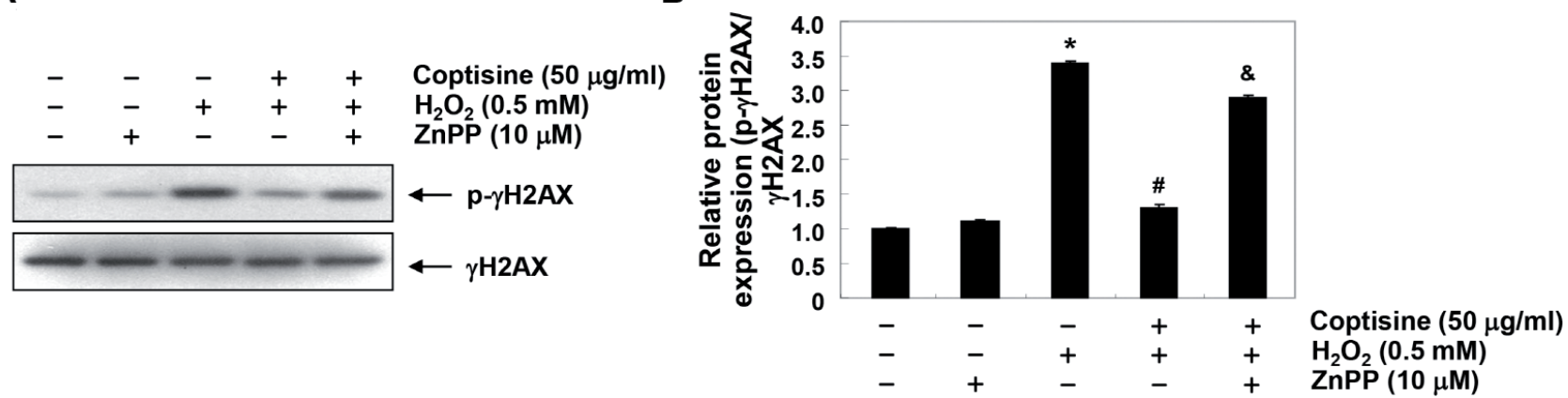

C
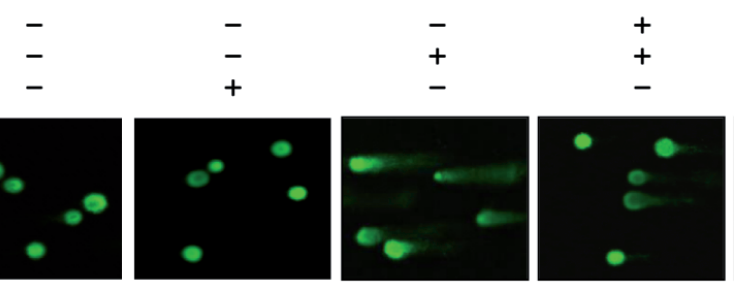

$+\quad$ Coptisine $(50 \mu \mathrm{g} / \mathrm{ml})$

$+\mathrm{H}_{2} \mathrm{O}_{2}(0.5 \mathrm{mM})$
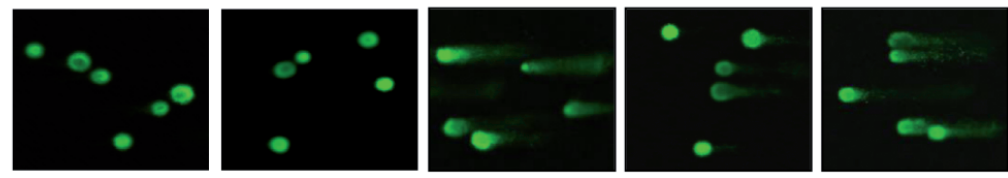

D

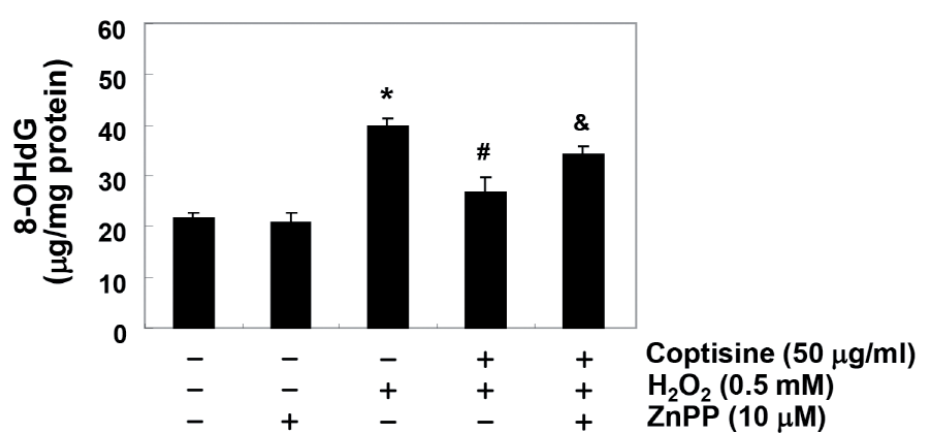

Figure 4. Protection of $\mathrm{H}_{2} \mathrm{O}_{2}$-induced DNA damage by coptisine in $\mathrm{HaCaT}$ cells. Cells were pretreated with $50 \mu \mathrm{g} / \mathrm{ml}$ coptisine and/or $10 \mu \mathrm{M} \mathrm{ZnPP}$ for $1 \mathrm{~h}$, and then stimulated with or without $0.5 \mathrm{mM} \mathrm{H}_{2} \mathrm{O}_{2}$ for $24 \mathrm{~h}$. A. Cell lysates were subjected to gel electrophoresis, and then Western blot analysis was performed using anti- $\gamma \mathrm{H} 2 \mathrm{AX}$ and $-\mathrm{p}-\gamma \mathrm{H} 2 \mathrm{AX}$ antibodies. B. Bands were quantified using Image and ratios were determined to the relative values of phosphorylated form relative to the total protein amount of $\gamma \mathrm{H} 2 \mathrm{AX}$. C. Comet assay was used to assess DNA damage (original magnification, 200×). D. The 8-OHdG content in cellular DNA was measured with an EIA kit $\left({ }^{*} p<0.05\right.$ compared with the control group, ${ }^{\sharp} p<0.05$ compared with the $\mathrm{H}_{2} \mathrm{O}_{2}$-treated group, ${ }^{\&} p<0.05$ compared with the coptisine and $\mathrm{H}_{2} \mathrm{O}_{2}$-treated group). 


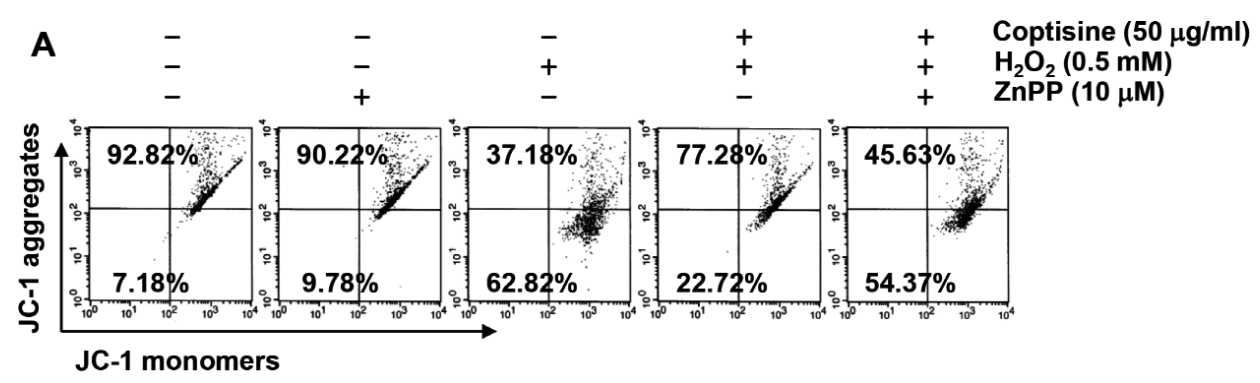

B

C
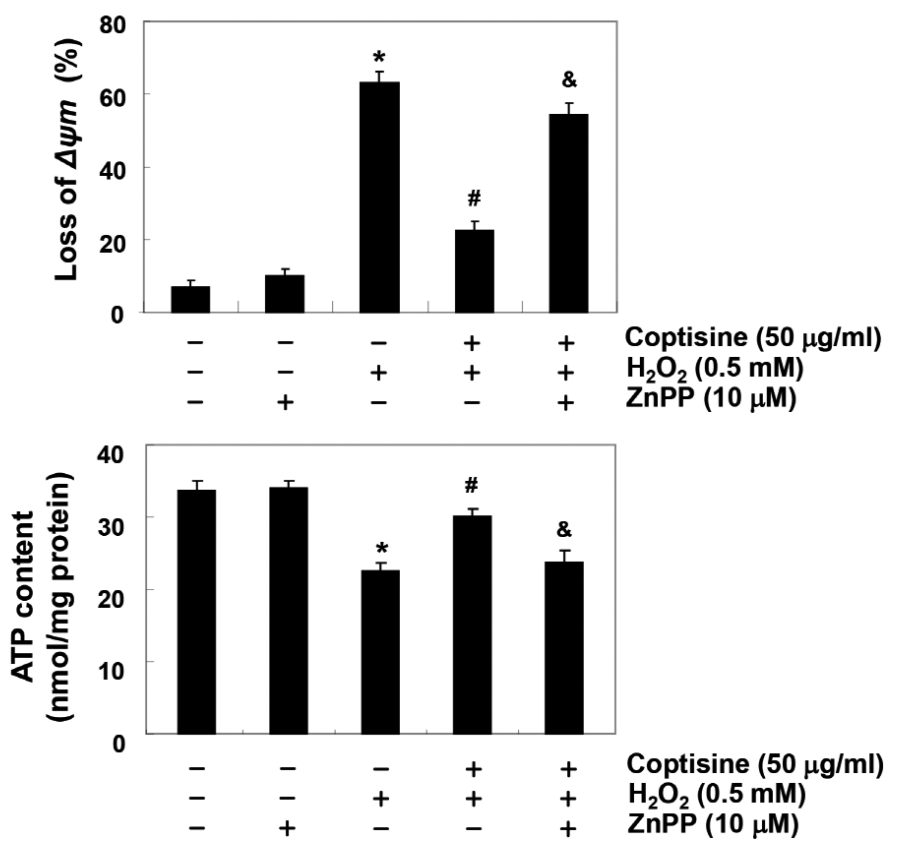

Figure 5. Attenuation of $\mathrm{H}_{2} \mathrm{O}_{2}$ induced mitochondrial dysfunction by coptisine in $\mathrm{HaCaT}$ cells. Cells were pretreated with $50 \mu \mathrm{g} /$ $\mathrm{ml}$ coptisine and/or $10 \mu \mathrm{M} \mathrm{ZnPP}$ for $1 \mathrm{~h}$, and then stimulated with or without $0.5 \mathrm{mM} \mathrm{H}_{2} \mathrm{O}_{2}$ for 24 h. A., B. The values of MMP were evaluated by a flow cytometer $\left({ }^{*} p<0.05\right.$ compared with the control group, ${ }^{\#} p<0.05$ compared with the $\mathrm{H}_{2} \mathrm{O}_{2}$-treated group, ${ }^{\&} p<0.05$ compared with the coptisine and $\mathrm{H}_{2} \mathrm{O}_{2}$-treated group). C. The ATP contents were measured with a commercially available kit was used $\left({ }^{*} p<\right.$ 0.05 compared with the control group, ${ }^{\#} p<0.05$ compared with the $\mathrm{H}_{2} \mathrm{O}_{2}$-treated group, ${ }^{\&} p<$ 0.05 compared with the coptisine and $\mathrm{H}_{2} \mathrm{O}_{2}$-treated group). important components of cells, such as nucleic acids, proteins, and lipids, ultimately leading to oxidative damage (Valko et al. 2016; Treberg et al. 2019). $\mathrm{H}_{2} \mathrm{O}_{2}$, one of the major ROS, is nonradical 2-electron reduction product of oxygen. Although the concentration of $\mathrm{H}_{2} \mathrm{O}_{2}$ acting as a messenger molecule varies depending on the cell type (Sies 2014), $\mathrm{H}_{2} \mathrm{O}_{2}$ dissociates in the cell to form reactive and destructive hydroxyl radicals that contribute to DNA damage and subsequent apoptosis (Rezvani et al. 2007; Piao et al. 2012). Recently, $\mathrm{H}_{2} \mathrm{O}_{2}$-induced oxidative stress has been shown to induce apoptosis through mitochondrial dysfunction in keratinocytes (Sun et al. 2017; Yoon et al. 2017). Therefore, in this study, exogenous $\mathrm{H}_{2} \mathrm{O}_{2}$ treatment was selected as an inducer of oxidative damage to $\mathrm{HaCaT}$ keratinocytes. The current results demonstrate that coptisine prevented $\mathrm{H}_{2} \mathrm{O}_{2}$-induced DNA damage and apoptosis of $\mathrm{HaCaT}$ keratinocyte through the rescue of mitochondrial function by blocking ROS accumulation. The results also demonstrate that coptisine promoted activation of the $\mathrm{Nrf} 2 /$ HO-1 signaling pathway, and inhibition of HO-1 activity eliminated the protective effect of coptisine, suggesting that the protective action of coptisine on $\mathrm{HaCaT}$ cells was at least Nrf2-mediated HO-1 dependent.

It is well known that Nrf2 is a ubiquitous transcription factor, which plays the role of a central regulator in protecting cells from oxidative damage (Kobayashi and Yamamoto 2005; Lee et al. 2011a; Qiu et al. 2014). Among one of the Nrf2-dependent cytoprotective enzymes, HO-1 plays a critical role in heme catabolism, and produces biliverdin, ferrous iron, and carbon monoxide. This enzyme is also activated in response to various oxidative signals, and provides adaptive and beneficial cellular responses to oxidative damage, not limited to the degradation of toxic heme released by hemoproteins (Kobayashi and Yamamoto 2005; Loboda et al. 2016). The results show that $\mathrm{H}_{2} \mathrm{O}_{2}$ alone partially increases the expression of $\mathrm{HO}-1$, as well as the expression and phosphorylation of Nrf2, which were further markedly increased by the co-treatment with coptisine, compared to that of the cells treated $\mathrm{H}_{2} \mathrm{O}_{2}$ alone. However, transient knockdown of Nrf2 with Nrf2-siRNA markedly reduced coptisine-mediated Nrf2 activation and HO-1 induction, which is evidence that the increased HO-1 expression is 
A

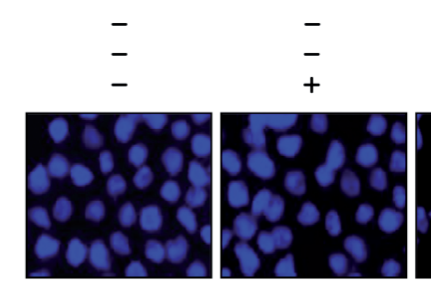

\section{王}

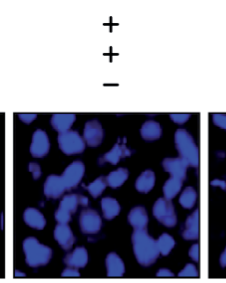

$+\quad$ Coptisine $(50 \mu \mathrm{g} / \mathrm{ml})$
$+\quad \mathrm{H}_{2} \mathrm{O}_{2}(0.5 \mathrm{mM})$

$+\mathrm{ZnPP}(10 \mu \mathrm{M})$
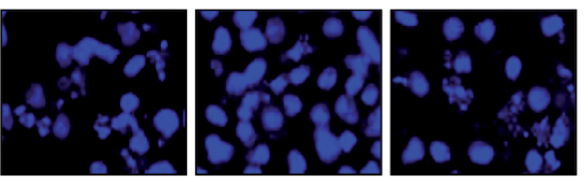

B

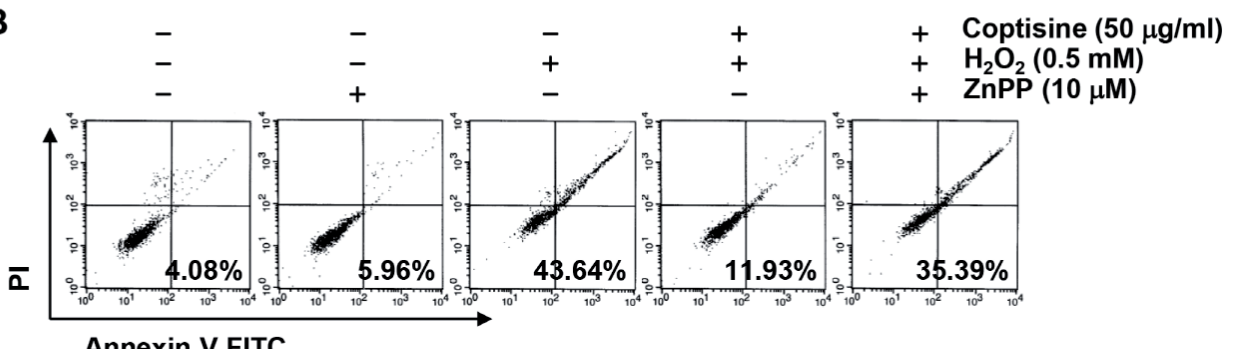

Annexin V FITC

C

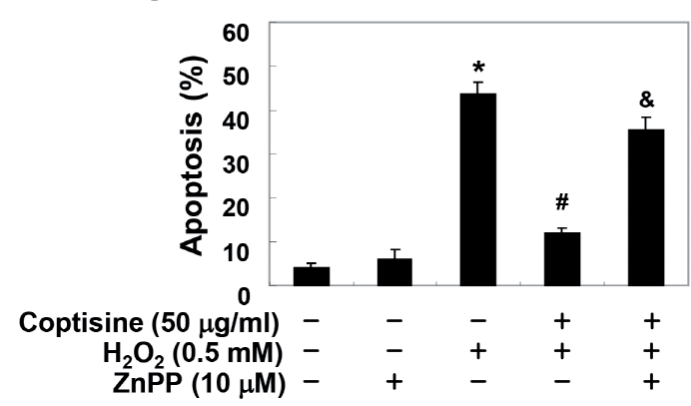

D

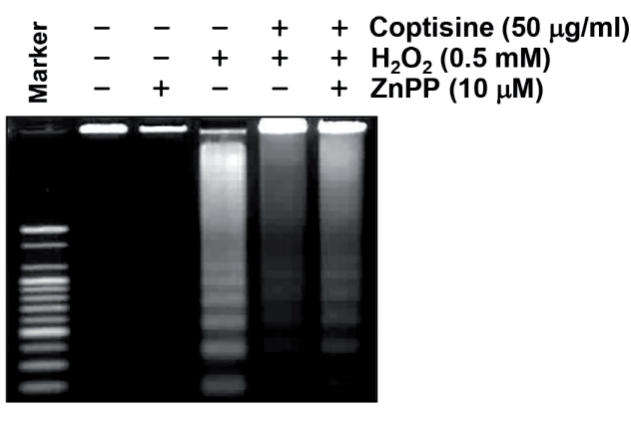

Figure 6. Suppression of $\mathrm{H}_{2} \mathrm{O}_{2}$-induced apoptosis by coptisine in $\mathrm{HaCaT}$ cells. Cells were treated with $50 \mu \mathrm{g} / \mathrm{ml}$ coptisine and/or $10 \mu \mathrm{M}$ $\mathrm{ZnPP}$ for $1 \mathrm{~h}$, and then stimulated with or without $0.5 \mathrm{mM} \mathrm{H}_{2} \mathrm{O}_{2}$ for $24 \mathrm{~h}$. A. The DAPI-stained nuclei were observed using a fluorescence microscope (original magnification, $400 \times$ ). B., C. The percentages of apoptotic cells were then analyzed using flow cytometric analysis $\left({ }^{*} p<0.05\right.$ compared with the control group, ${ }^{\#} p<0.05$ compared with the $\mathrm{H}_{2} \mathrm{O}_{2}$-treated group, ${ }^{\&} p<0.05$ compared with the coptisine and $\mathrm{H}_{2} \mathrm{O}_{2}$-treated group). D. DNA fragmentation was analyzed by an agarose gel electrophoresis. The results are representative of those obtained from three independent experiments.

mediated by Nrf2. Additionally, transient knockdown of $\mathrm{Nrf2}$ and ZnPP, an HO-1 specific inhibitor, caused the coptisine-induced preventive effects in $\mathrm{H}_{2} \mathrm{O}_{2}$-induced reduction of cell viability to completely disappear.

Similar to the results of this study, previous studies have shown that $\mathrm{H}_{2} \mathrm{O}_{2}$ alone can induce the expression of HO-1 (Aggeli et al. 2006; Lee et al. 2011b), and the up-regulation of $\mathrm{HO}-1$ has been identified as a defense mechanism against $\mathrm{H}_{2} \mathrm{O}_{2}$-induced apoptosis in a variety of cell types, including keratinocytes (Hseu et al. 2015; Yoon et al. 2017; Yang et al. 2018). In addition, overexpression of HO-1 exhibited resistance to DNA damage and apoptosis induced by oxidative stress (Kobayashi and Yamamoto 2005; Hseu et al. 2015; Loboda et al. 2016); however, inhibition of HO-1 activity improved cytotoxicity against oxidative stress, and reduced the efficacy of antioxidants (Hirai et al. 2007; Zhu et al. 2014, 2015). Thus, the effect of ZnPP on the inhibitory effect of ROS production by coptisine was investigated in $\mathrm{H}_{2} \mathrm{O}_{2}$-treated $\mathrm{HaCaT}$ keratinocytes, and it was observed that ZnPP treatment significantly abolished the beneficial effect of ROS production by coptisine. These results suggest that the protective effect of coptisine on $\mathrm{H}_{2} \mathrm{O}_{2}$-induced oxidative stress is mediated through the activation of $\mathrm{Nrf} 2 / \mathrm{HO}-1$ signaling. Furthermore, ZnPP significantly diminished the inhibitory effect of coptisine on $\mathrm{H}_{2} \mathrm{O}_{2}$-induced DNA damage, which also implies that the protective role of coptisine on $\mathrm{H}_{2} \mathrm{O}_{2}$-induced cytotoxicity was dependent on the HO-1 in $\mathrm{HaCaT}$ keratinocytes.

Ample experimental evidence has shown that mitochondria in keratinocytes are the primary intracellular organelle of $\mathrm{H}_{2} \mathrm{O}_{2}$ toxicity, while excessive accumulation of ROS by oxidative stress is one of the mechanisms leading to apoptosis associated with mitochondrial injury (Sun et al. 2017; Yoon et al. 2017). In addition, HO-1 activation in keratinocytes 
is recognized as a cytoprotective mechanism against oxidative stress-mediated mitochondrial dysfunction, through inactivation of the mitochondria-mediated intrinsic apoptosis pathway (Zhu et al. 2014; Hseu et al. 2015; Duan et al. 2016). In the induction of ROS-mediated apoptosis, ROS causes free radical attack of the mitochondrial membrane phospholipid. As a result, mitochondrial membrane depolarization occurs and MMP is lost, which is considered to be an onset of intrinsic apoptosis pathway (Finkel and Holbrook 2000; Rigoulet et al. 2011). At the same time, mitochondrial dysfunction disrupts the production of intracellular ATP, by promoting abnormalities in the electron transport pathway of the mitochondrial respiratory chain (D'Autréaux et al. 2007; Valero 2014). Ultimately, intracellular ATP levels can be used as an indicator of the homeostasis of mitochondrial energy metabolism (Orrenius 2007; Cui et al. 2017). The current studies show that when cells were exposed to $\mathrm{H}_{2} \mathrm{O}_{2}$, MMP levels and ATP contents were significantly reduced compared to controls, whereas coptisine reversed the loss of $\mathrm{MMP}$ and APT by $\mathrm{H}_{2} \mathrm{O}_{2}$. However, in the presence of $\mathrm{ZnPP}$, coptisine-mediated repair of mitochondrial dysfunction and decrease of ATP production were significantly abolished. In view of maintaining energy homeostasis, these results are in good agreement with previous studies that show that the protective effect of apoptosis on oxidative stress is related to the maintenance of ATP production by the preservation of mitochondrial function (Mao et al. 2014; Tian et al. 2017). Therefore, the conservation of ATP production by the maintenance of mitochondrial function is considered to be a possible mechanism by which coptisine can preserve keratinocyte survival pathway from oxidative stress through HO- 1 activation.

The activation of apoptosis through caspase cascade is regulated by various proteins, including $\mathrm{Bcl}-2$ family members that consist of anti-apoptotic and pro-apoptotic proteins. Among the Bcl-2 family members, anti-apoptotic proteins, such as $\mathrm{Bcl}-2$, are located on the outer mitochondrial membrane to prevent the release of apoptogenic factors, and provide protection by inhibiting the consumption of ATP (Gustafsson and Gottlieb 2007; Kiraz et al. 2016). On the other hand, pro-apoptotic proteins, including Bax, antagonize anti-apoptotic proteins, or translocate to mitochondrial

A

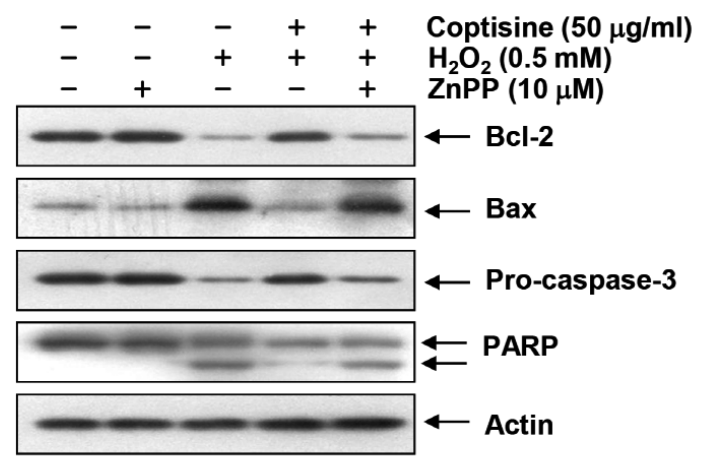

C

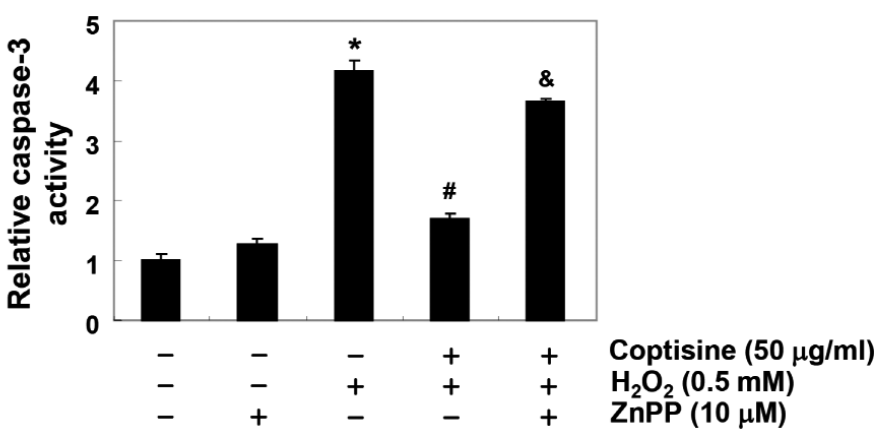

B
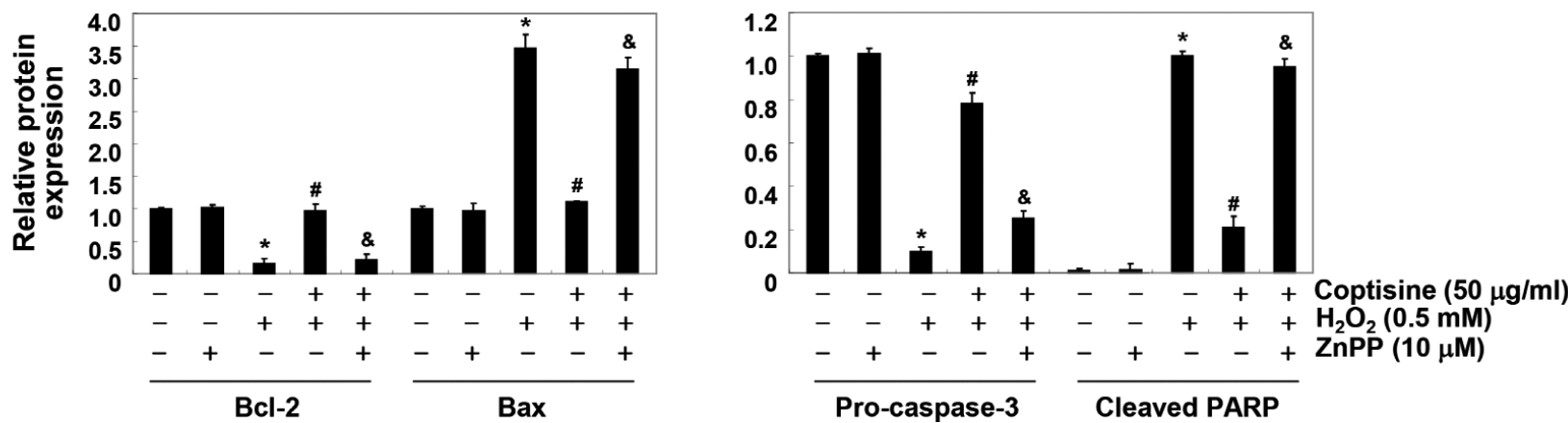

Figure 7. Effect of coptisine on the expression of apoptosis regulatory genes in $\mathrm{H}_{2} \mathrm{O}_{2}$-treated $\mathrm{HaCaT}$ cells. A., B. After treatment with $50 \mu \mathrm{g} / \mathrm{ml}$ coptisine and/or $10 \mu \mathrm{M} \mathrm{ZnPP}$ in the presence or absence of $0.5 \mathrm{mM} \mathrm{H}_{2} \mathrm{O}_{2}$ for $24 \mathrm{~h}$, the cellular proteins were subjected to gel electrophoresis, and then Western blot analysis was performed using the indicated antibodies. Actin was used as an internal control. B. Bands were quantified using ImageJ, normalized to actin and ratios were determined. C. The caspase- 3 activity was measured using an ELISA microplate reader $\left({ }^{*} p<0.05\right.$ compared with the control group, ${ }^{\#} p<0.05$ compared with the $\mathrm{H}_{2} \mathrm{O}_{2}$-treated group, ${ }^{\&} p<0.05$ compared with the coptisine and $\mathrm{H}_{2} \mathrm{O}_{2}$-treated group). 
membranes to form membrane-integrated homo oligomers that induce mitochondrial pore formation, leading to the loss of MMP, resulting in the cytosolic release of apoptogenic factors (Imahashi et al. 2004; Kulikov et al. 2012). Thus, the balance of apoptotic Bax family proteins to anti-apoptotic Bcl-2 family proteins serves as a determinant to induce or inhibit the initiation of the intrinsic apoptosis pathway. Many previous studies have shown that the induction of apoptosis by $\mathrm{H}_{2} \mathrm{O}_{2}$ in keratinocytes was associated with a decrease in the $\mathrm{Bcl}-2 / \mathrm{Bax}$ ratio and/or activation of caspases (Kanda and Watanabe 2003; Sun et al. 2017). The present results show that the presence of coptisine reversed the decreased expression of $\mathrm{Bcl}-2$, and increased the expression of Bax observed in $\mathrm{H}_{2} \mathrm{O}_{2}$-treated $\mathrm{HaCaT}$ keratinocytes. In addition, coptisine administration blocked the $\mathrm{H}_{2} \mathrm{O}_{2}$-induced activation of caspase-3, and the degradation of PARP, concomitant with reduced apoptosis. In this respect, it is suggested that coptisine can rescue $\mathrm{H}_{2} \mathrm{O}_{2}$-induced cytotoxic injury by blocking mitochondria-mediated apoptosis. However, the inhibition of HO-1 function using an HO-1 inhibitor markedly hindered these protective effects. These results are in good agreement with other recent studies that show that $\mathrm{HO}-1$ restored cell survival through the prevention of oxidative damage-mediated apoptosis (Yu et al. 2013; Chen et al. 2017; Zhang et al. 2018), indicating that the cellular protective potential of coptisine against oxidative stress in $\mathrm{HaCaT}$ keratinocytes is at least dependent on the activation of $\mathrm{Nrf} 2 / \mathrm{HO}-1$ signaling.

In summary, the current study demonstrates that coptisine can effectively protect $\mathrm{HaCaT}$ keratinocytes from $\mathrm{H}_{2} \mathrm{O}_{2}$ induced cytotoxicity, by blocking oxidative stress-mediated DNA damage and mitochondria-dependent apoptotic pathway, through $\mathrm{Nrf} / \mathrm{HO}-1$ signaling-mediated antioxidant action. Although studies on mitochondrial damage-associated energy metabolism and its associated signal molecules are needed, the present findings may be presented as evidence that coptisine can alter the redox state of keratinocytes, and thereby regulate cellular antioxidant signaling pathways.

Conflict of interest: The author has no conflict of interest to declare.

\section{References}

Aggeli IK, Gaitanaki C, Beis I (2006): Involvement of JNKs and p38-MAPK/MSK1 pathways in $\mathrm{H} 2 \mathrm{O} 2$-induced upregulation of heme oxygenase-1 mRNA in H9c2 cells. Cell. Signal. 18, $1801-1812$ https://doi.org/10.1016/j.cellsig.2006.02.001

Chen H, Tang X, Zhou B, Zhou Z, Xu N, Wang Y (2017): A ROSmediated mitochondrial pathway and $\mathrm{Nrf2}$ pathway activation are involved in BDE-47 induced apoptosis in Neuro-2a cells. Chemosphere 184, 679-686

https://doi.org/10.1016/j.chemosphere.2017.06.006
Cheng CF, Zerzan JC, Johnson DB, Juul SE (2012): Zinc protoporphyrin-to-heme ratios in high-risk and preterm infants. J. Pediatr. 161, 81-87 https://doi.org/10.1016/j.jpeds.2011.12.048

Cho EJ, Yokozawa T, Rhee SH, Park KY (2004): The role of Coptidis Rhizoma extract in a renal ischemia-reperfusion model. Phytomedicine 11, 576-584 https://doi.org/10.1016/j.phymed.2003.07.005

Cui L, Li Z, Chang X, Cong G, Hao L (2017): Quercetin attenuates vascular calcification by inhibiting oxidative stress and mitochondrial fission. Vascul. Pharmacol. 88, 21-29 https://doi.org/10.1016/j.vph.2016.11.006

D‘Autréaux B, Toledano MB (2007): ROS as signalling molecules: mechanisms that generate specificity in ROS homeostasis. Nat. Rev. Mol. Cell. Biol. 8, 813-824 https://doi.org/10.1038/nrm2256

D'Errico M, Lemma T, Calcagnile A, Proietti De Santis L, Dogliotti E (2007): Cell type and DNA damage specific response of human skin cells to environmental agents. Mutat. Res. 614, 37-47 https://doi.org/10.1016/j.mrfmmm.2006.06.009

Duan X, Li J, Li W, Xing X, Zhang Y, Li W, Zhao L, Sun G, Gao XH, Li B (2016): Antioxidant tert-butylhydroquinone ameliorates arsenic-induced intracellular damages and apoptosis through induction of Nrf2-dependent antioxidant responses as well as stabilization of anti-apoptotic factor Bcl-2 in human keratinocytes. Free Radic. Biol. Med. 94, 74-87

https://doi.org/10.1016/j.freeradbiomed.2016.02.009

Fang J, Seki T, Maeda H (2009): Therapeutic strategies by modulating oxygen stress in cancer and inflammation. Adv. Drug Deliv. Rev. 61, 290-302 https://doi.org/10.1016/j.addr.2009.02.005

Finkel T, Holbrook NJ (2000): Oxidants, oxidative stress and the biology of ageing. Nature 408, 239-247

https://doi.org/10.1038/35041687

Gong LL, Fang LH, Wang SB, Sun JL, Qin HL, Li XX, Wang SB, Du GH (2012): Coptisine exert cardioprotective effect through anti-oxidative and inhibition of RhoA/Rho kinase pathway on isoproterenol-induced myocardial infarction in rats. Atherosclerosis 222, 50-58

https://doi.org/10.1016/j.atherosclerosis.2012.01.046

Gustafsson AB, Gottlieb RA (2007): Bcl-2 family members and apoptosis, taken to heart. Am. J. Physiol. Cell. Physiol. 292, C45-51 https://doi.org/10.1152/ajpcell.00229.2006

Hirai K, Sasahira T, Ohmori H, Fujii K, Kuniyasu H (2007): Inhibition of heme oxygenase- 1 by zinc protoporphyrin IX reduces tumor growth of LL/2 lung cancer in C57BL mice. Int. J. Cancer 120, 500-505 https://doi.org/10.1002/ijc.22287

Hjortsø MD, Andersen MH (2014): The expression, function and targeting of haem oxygenase- 1 in cancer. Curr. Cancer Drug Targets 14, 337-347

https://doi.org/10.2174/1568009614666140320111306

Hseu YC, Lo HW, Korivi M, Tsai YC, Tang MJ, Yang HL (2015): Dermato-protective properties of ergothioneine through induction of Nrf2/ARE-mediated antioxidant genes in UVA-irradiated human keratinocytes. Free Radic. Biol. Med. 86, 102-117 https://doi.org/10.1016/j.freeradbiomed.2015.05.026 
Hu YR, Ma H, Zou ZY, He K, Xiao YB, Wang Y, Feng M, Ye XL, Li XG (2017): Activation of Akt and JNK/Nrf2/NQO1 pathway contributes to the protective effect of coptisine against AAPH-induced oxidative stress. Biomed. Pharmacother. 85, 313-322 https://doi.org/10.1016/j.biopha.2016.11.031

Imahashi K, Schneider MD, Steenbergen C, Murphy E (2004): Transgenic expression of Bcl-2 modulates energy metabolism, prevents cytosolic acidification during ischemia, and reduces ischemia/reperfusion injury. Circ. Res. 95, 734-741 https://doi.org/10.1161/01.RES.0000143898.67182.4c

Jang MH, Kim HY, Kang KS, Yokozawa T, Park JH (2009): Hydroxyl radical scavenging activities of isoquinoline alkaloids isolated from Coptis chinensis. Arch. Pharm. Res. 32, 341-345 https://doi.org/10.1007/s12272-009-1305-Z

Jung HA, Min BS, Yokozawa T, Lee JH, Kim YS, Choi JS (2009): Anti-Alzheimer and antioxidant activities of Coptidis Rhizoma alkaloids. Biol. Pharm. Bull. 32, 1433-1438 https://doi.org/10.1248/bpb.32.1433

Kanda N, Watanabe S (2003): 17beta-estradiol inhibits oxidative stress-induced apoptosis in keratinocytes by promoting Bcl-2 expression. J. Invest. Dermatol. 121, 1500-1509 https://doi.org/10.1111/j.1523-1747.2003.12617.x

Kim MY, Choi EO, HwangBo H, Kwon DH, Ahn KI, Kim HJ, Ji SY, Hong SH, Jeong JW, Kim GY, Park C, Choi YH (2018): Reactive oxygen species-dependent apoptosis induction by water extract of Citrus unshiu peel in MDA-MB-231 human breast carcinoma cells. Nutr. Res. Pract. 12, 129-134 https://doi.org/10.4162/nrp.2018.12.2.129

Kiraz Y, Adan A, Kartal Yandim M, Baran Y (2016): Major apoptotic mechanisms and genes involved in apoptosis. Tumour Biol. 37, 8471-8486 https://doi.org/10.1007/s13277-016-5035-9

Kobayashi M, Yamamoto M (2005): Molecular mechanisms activating the Nrf2-Keap1 pathway of antioxidant gene regulation. Antioxid. Redox Signal. 7, 385-394 https://doi.org/10.1089/ars.2005.7.385

Kulikov AV, Shilov ES, Mufazalov IA, Gogvadze V, Nedospasov SA, Zhivotovsky B (2012): Cytochrome c: the Achilles' heel in apoptosis. Cell. Mol. Life Sci. 69, 1787-1797 https://doi.org/10.1007/s00018-011-0895-z

Kulms D, Schwarz T (2002): Independent contribution of three different pathways to ultraviolet-B-induced apoptosis. Biochem. Pharmacol. 64, 837-841 https://doi.org/10.1016/S0006-2952(02)01146-2

Kuribayashi K, Iida S, Nakajima Y, Funaguchi N, Tabata C, Fukuoka K, Fujimori Y, Ihaku D, Nakano T (2015): Suppression of heme oxygenase-1 activity reduces airway hyperresponsiveness and inflammation in a mouse model of asthma. J. Asthma 52, 662-668 https://doi.org/10.3109/02770903.2015.1008138

Lee SE, Jeong SI, Kim GD, Yang H, Park CS, Jin YH, Park YS (2011a): Upregulation of heme oxygenase-1 as an adaptive mechanism for protection against crotonaldehyde in human umbilical vein endothelial cells. Toxicol. Lett. 201, 240-248 https://doi.org/10.1016/j.toxlet.2011.01.006

Lee SE, Jeong SI, Yang H, Park CS, Jin YH, Park YS (2011b): Fisetin induces Nrf2-mediated HO- 1 expression through PKC- $\delta$ and p38 in human umbilical vein endothelial cells. J. Cell. Biochem. 112, 2352-2360 https://doi.org/10.1002/jcb.23158

Loboda A, Damulewicz M, Pyza E, Jozkowicz A, Dulak J (2016): Role of Nrf2/HO-1 system in development, oxidative stress response and diseases: an evolutionarily conserved mechanism. Cell. Mol. Life Sci. 73, 3221-3247 https://doi.org/10.1007/s00018-016-2223-0

Luo JF, Shen XY, Lio CK, Dai Y, Cheng CS, Liu JX, Yao YD, Yu Y, Xie Y, Luo P, Yao XS, Liu ZQ, Zhou H (2018): Activation of Nrf2/ HO-1 pathway by nardochinoid $\mathrm{C}$ inhibits inflammation and oxidative stress in lipopolysaccharide-stimulated macrophages. Front. Pharmacol. 9, 911 https://doi.org/10.3389/fphar.2018.00911

Mao CY, Lu HB, Kong N, Li JY, Liu M, Yang CY, Yang P (2014): Levocarnitine protects $\mathrm{H} 9 \mathrm{c} 2$ rat cardiomyocytes from $\mathrm{H} 2 \mathrm{O} 2$ induced mitochondrial dysfunction and apoptosis. Int. J. Med. Sci. 11, 1107-1115 https://doi.org/10.7150/ijms.9153

Meng FC, Wu ZF, Yin ZQ, Lin LG, Wang R, Zhang QW (2018): Coptidis rhizoma and its main bioactive components: recent advances in chemical investigation, quality evaluation and pharmacological activity. Chin. Med. 13, 13 https://doi.org/10.1186/s13020-018-0171-3

Orrenius S (2007): Reactive oxygen species in mitochondriamediated cell death. Drug Metab. Rev. 39, 443-455 https://doi.org/10.1080/03602530701468516

Park C, Hong SH, Shin SS, Lee DS, Han MH, Cha HJ, Kim S, Kim HS, Kim GY, Park EK, Jeon YJ, Choi YH (2018): Activation of the Nrf2/HO-1 signaling pathway contributes to the protective effects of Sargassum serratifolium extract against oxidative stress-induced DNA damage and apoptosis in SW1353 human chondrocytes. Int. J. Environ. Res. Public Health 15, E1173 https://doi.org/10.3390/ijerph15061173

Piao MJ, Zhang R, Lee NH, Hyun JW (2012): Protective effect of triphlorethol-A against ultraviolet B-mediated damage of human keratinocytes. J. Photochem. Photobiol. B 106, 74-80 https://doi.org/10.1016/j.jphotobiol.2011.10.007

Qiu L, Song Z, Setaluri V (2014): Oxidative stress and vitiligo: the Nrf2-ARE signaling connection. J. Invest. Dermatol. 134, 2074-2076 https://doi.org/10.1038/jid.2014.241

Rezvani HR, Cario-André M, Pain C, Ged C, deVerneuil H, Taïeb A (2007): Protection of normal human reconstructed epidermis from UV by catalase overexpression. Cancer Gene Ther. 14, 174-186 https://doi.org/10.1038/sj.cgt.7701000

Rigoulet M, Yoboue ED, Devin A (2011): Mitochondrial ROS generation and its regulation: mechanisms involved in $\mathrm{H} 2 \mathrm{O} 2$ signaling. Antioxid. Redox Signal. 14, 459-468 https://doi.org/10.1089/ars.2010.3363

Sies H (2014): Role of metabolic H2O2 generation: redox signaling and oxidative stress. J. Biol. Chem. 289, 8735-8741 https://doi.org/10.1074/jbc.R113.544635

Sosa V, Moliné T, Somoza R, Paciucci R, Kondoh H, LLeonart ME (2013): Oxidative stress and cancer: an overview. Ageing Res. Rev. 12, 376-390 https://doi.org/10.1016/j.arr.2012.10.004 
Sun Y, Zhou C, Huang S, Jiang C (2017): Selenium polysaccharide SPMP-2a from Pleurotus geesteranus alleviates $\mathrm{H} 2 \mathrm{O} 2$-induced oxidative damage in HaCaT cells. Biomed. Res. Int. 2017, 4940384 https://doi.org/10.1155/2017/4940384

Tian X, He W, Yang R, Liu Y (2017): Dl-3-n-butylphthalide protects the heart against ischemic injury and $\mathrm{H} 9 \mathrm{c} 2$ cardiomyoblasts against oxidative stress: involvement of mitochondrial function and biogenesis. J. Biomed. Sci. 24, 38 https://doi.org/10.1186/s12929-017-0345-9

Treberg JR, Braun K, Selseleh P (2019): Mitochondria can act as energy-sensing regulators of hydrogen peroxide availability. Redox Biol. 20, 483-488 https://doi.org/10.1016/j.redox.2018.11.002

Valero T (2014): Mitochondrial biogenesis: pharmacological approaches. Curr. Pharm. Des. 20, 5507-5509 https://doi.org/10.2174/138161282035140911142118

Valko M, Jomova K, Rhodes CJ, Kuča K, Musílek K (2016): Redoxand non-redox-metal-induced formation of free radicals and their role in human disease. Arch. Toxicol. 90, 1-37 https://doi.org/10.1007/s00204-015-1579-5

Xu Z, Feng W, Shen Q, Yu N, Yu K, Wang S, Chen Z, Shioda S, Guo $\mathrm{Y}$ (2017): Rhizoma coptidis and berberine as a natural drug to combat aging and aging-related diseases via anti-oxidation and AMPK activation. Aging Dis. 8, 760-777 https://doi.org/10.14336/AD.2016.0620

Yang HL, Lee CL, Korivi M, Liao JW, Rajendran P, Wu JJ, Hseu YC (2018): Zerumbone protects human skin keratinocytes against UVA-irradiated damages through Nrf2 induction. Biochem. Pharmacol. 148, 130-146 https://doi.org/10.1016/j.bcp.2017.12.014

Yokozawa T, Ishida A, Kashiwada Y, Cho EJ, Kim HY, Ikeshiro Y (2004): Coptidis Rhizoma: protective effects against peroxyni- trite-induced oxidative damage and elucidation of its active components. J. Pharm. Pharmacol. 56, 547-556 https://doi.org/10.1211/0022357023024

Yoon JJ, Jeong JW, Choi EO, Kim MJ, Hwang-Bo H, Kim HJ, Hong SH, Park C, Lee DH, Choi YH (2017): Protective effects of Scutellaria baicalensis Georgi against hydrogen peroxideinduced DNA damage and apoptosis in HaCaT human skin keratinocytes. EXCLI J. 16, 426-438

Yu J, Zhu X, Qi X, Che J, Cao B (2013): Paeoniflorin protects human EA.hy926 endothelial cells against gamma-radiation induced oxidative injury by activating the NF-E2-related factor $2 /$ heme oxygenase-1 pathway. Toxicol. Lett. 218, 224-234 https://doi.org/10.1016/j.toxlet.2013.01.028

Zhang XT, Sun XQ, Wu C, Chen JL, Yuan JJ, Pang QF, Wang ZP (2018): Heme oxygnease-1 induction by methylene blue protects RAW264.7 cells from hydrogen peroxide-induced injury. Biochem. Pharmacol. 48, 265-277 https://doi.org/10.1159/000139189

Zhu W, Xu J, Ge Y, Cao H, Ge X, Luo J, Xue J, Yang H, Zhang S, Cao J (2014): Epigallocatechin-3-gallate (EGCG) protects skin cells from ionizing radiation via heme oxygenase-1 (HO-1) overexpression. J. Radiat. Res. 55, 1056-1065 https://doi.org/10.1093/jrr/rru047

Zhu XF, Li W, Ma JY, Shao N, Zhang YJ, Liu RM, Wu WB, Lin Y, Wang SM (2015): Knockdown of heme oxygenase-1 promotes apoptosis and autophagy and enhances the cytotoxicity of doxorubicin in breast cancer cells. Oncol. Lett. 10, 2974-2980 https://doi.org/10.3892/ol.2015.3735

Received: February 15, 2019

Final version accepted: April 9, 2019

First published online: June 20, 2019 